\title{
Community Approach: A Novel Way to Assess the Performance of Improved Vegetable Varieties
}

\author{
Ashwini Kumar Tiwari ${ }^{1 *}$ and Jugul Kishor Tiwari ${ }^{2}$ \\ ${ }^{1}$ Fiji National University, College of agriculture, Fisheries and forestry, Koronivia, Fiji islands \\ ${ }^{2}$ Indira Gandhi agricultural university, Raipur, Chhattisgarh, India \\ *Corresponding author
}

\author{
A B S T R A C T
}

Bastar is one of the important district of Chhattisgarh, normally inhabited by tribe, among them, the dominants are Gond, Bhatra, Maria and Muria. These tribes are normally practicing in traditional farming. To make them aware with new technology, Front line demonstration of nine improved varieties viz. Kashi Anupam and Arka vikas in Tomato, Pant samrat in brinjal, Pusa sadabahar in chilli, Arkel in pea, Pusa komal and Pusa phalguni in cow pea, Arka anamika and Pusa A-4 in okra along with recommended technology were demonstrated in randomly selected 120 farmers field in an area of 12 hectares covering five villages of Bastanar block, during 2009 - 2011. Performance of demonstrated varieties was better in terms of yield with a minimum of 23.40 percent in Pea to maximum of 52.30 percent in chilli over the existing local cultivars. The extension index of 18.94 percent to 34.34 percent reflects ample opportunity for seed replacement in demonstrated area. Analysis of data reveals that technology index vary from 11.33 to 19.5 which are on lower side indicating greater scope for adoption of improved vegetable varieties by the farmers.

\section{Introduction}

In vegetables, cultivation of solanaceous vegetables require much attention, Starting from nursery raising to field preparation, transplanting, plant protection, harvesting stage up to marketing. In the same way crops like cowpea, okra and pea require attention and knowledge regarding proper varietal selection, proper way of sowing, plant protection measures, picking stage, postharvest and their marketing to reap the benefit of the farming of these crops (Neeraj Et al., 2008). A number of varieties are released by the public organisation every year but their improper extension leads the farmer of growing only traditional variety and they are unable to reap the advantage of these new improved varieties. Bastar is one of the important district of Chhattisgarh, normally dominated by Gond, Bhatra, Maria and Muria tribes. Bastar is having a great potential of vegetable production round the year due to favourable soil and agro-climatic conditions. Majority of farmers in this region are still practicing traditional farming as they are unknown about quality vegetable seed of the public organization while seed of private seed companies are expensive and are also not readily available here in the remote areas. Therefore, for creating awareness amongst the framers efforts have been made to popularize 
the high yielding varieties of tomato, brinjal, chilli, cowpea, okra and pea along with their production and protection technologies through community approach. These recommended technologies have been demonstrated through front line demonstration (FLD) with an objective to evaluate the yield performance of improved varieties with existing cultivars at farmers' field.

\section{Materials and Methods}

The present study was conducted in five villagers of Lalaguda, Turangur, Pirmeta, Kilepal and Mutanpal of Bastanar block during Kharif (tomato, brinjal and chilli), Rabi (pea) and Zaid (okra and cowpea) during 2009-2011. A total of 9 varieties of different vegetables including two each in tomato (Arka Vikas and Kashi Anupam), okra (Arka anamika andPusa A-4), cowpea (Pusa komal and Pusa phalguni) and one each in chilli (Pusa sadabahar). Brinjal (pant samrat), and Pea (Arkel) were randomly demonstrated in 120 farmer's field in total of 12 hectare area. The demonstration and farmers plot were kept side by side with minimum plot size of 200 square meter to visualize the difference and making self-assessment by the farmers. The demonstration plots were regularly monitored and cross-sectional data on output of new improved varieties against traditional practices followed by farmers were collected. The collected data were further pooled for two year and analyse for estimation technology gap, extension gap and technology index of each demonstrated vegetable varieties.

\section{Demonstrated technologies under community approach}

Apart from improved varieties, following package and practices have been advocated in the cultivation of solanaceous vegetable crops (Pandey et al., 2003).

\section{Field preparation}

Deep ploughing during summer to destroy soil borne insect pest and disease pathogens. Soil treatment with trichoderma @ 5.0kg /ha before sowing and transplanting.

\section{Nursery raising technology}

Soil solarization of nursery beds in hot summer by covering with transparent polyethylene sheets for five weeks.

Seed treatment with trichoderma @ 2.0g + Imidachloprid @ 2.5g/kg seed.

Raising of nursery on beds raised $20 \mathrm{~cm}$ from the ground maintaining $20-25 \mathrm{~cm}$ space between two beds.

Sowing of seeds in lines made apart $5 \mathrm{~cm}$.

One spray of streptocycline @ 150ppm to manage bacterial blight of seedlings.

\section{Transplanting technology}

Transplanting on raised beds at a distance of $60 \times 45 \mathrm{~cm}$ (tomato and brinjal) and $60 \times 30 \mathrm{~cm}$ (chilli).

Soil drenching with Trichoderma @ 1\% at 20days after planting.

Collection and destruction of tomato plants affected by TLCV, chilli plants affected by leaf curl and branches and fruits of brinjal affected by shoot and fruit borer and need based application of cartap hydrochloride @ $1 \mathrm{~g} /$ liter of water.

Spraying of streptocycline @ 200ppm to control bacterial blight.

Weeding, topdressing of urea and earthing at 30days after transplanting. 


\section{Production technology}

\section{Okra and cowpea}

Sowing of okra and cowpea at $45 \times 30 \mathrm{~cm}$ distance on raised beds to save irrigation water. Seed treatment of okra with trichoderma@2g+Imidachloprid @2.5g/ $\mathrm{kg}$ of seed.

Seed treatment of cowpea with trichoderma @ 2g + Rhizobium culture @ 10g/kg seed.

Spray of Pendimethalin@3.3liter/ha mixing in 1000 liter of water within 48 hours of sowing to control weeds. Weeding, topdressing of urea and earthing at 30 days after sowing.

Spraying of Imidachloprid @ 0.3ml/ liter of water to manage white fly (vector of YVMV of okra) and thrips.

\section{Pea}

Seed treatment with trichoderma@2g+ Rhizobium culture @ 10g/kg of seed.

Line sowing of pea at a distance of $30 \times 5 \mathrm{~cm}$.

Spray of Pendimethalin @ 3.3 liter/ ha mixing in 1000 liter of water with 48 hours of sowing to control weeds.

Weeding and top dressing of urea @ 30 days after sowing.

\section{Results and Discussion}

\section{Tomato}

The result revealed that demonstrated varieties of tomato, Kashi Anupam and Arka Vikas fetched an average yield of 310q/ha at farmers field as against $215 \mathrm{q} / \mathrm{ha}$ in local check. The data given in table 1 shows the significant increase of tomato yield i.e. up to $51.45 \%$ and $37.10 \%$ respectively over control. Technology index of $17.35 \%$ in case of Kashi Anupam followed by Arka Vikas (13.60), which indicates that Kashi Anupam variety is performing best in the farmers filed. Since the technology index of both the demonstrated varieties lies in lower quarter that indicates the higher level of adoption of these varieties as also advocated for important solanaceous vegetable in Bastar region, similar report was also reported by (Rai et al., 2005) in eastern U.P. in tomato leaf curl virus (TLCV) is a major problem in tomato cultivation and the variety Kashi Anupam has showed moderately resistant during the early season cultivation of tomato, there is a great scope of its high adoptability among the growers, this is in confirmation to the performance observed by Neeraj et al., (2008). Seeing the good performance of Kashi Anupam and Arka Vikas in field, these varieties are becoming popular among the farmers.

\section{Brinjal}

Attempts were made to evaluate the performance of Pant samrat variety of brinjal at farmer's filed through demonstration. It produced an average yield of $305.50 \mathrm{q} / \mathrm{ha}$ with $32.70 \%$ increase over the local check. Therefore, its adoption was better in Bastar region. It also showed low technology index $(12.71 \%)$

\section{Chilli}

Chilli variety Pusa Sadabahar were evaluated in farmers filed, and comparison was made with the variety grown by farmers of these region. Result showed that this variety was an out yielder with an average yield of $145 \mathrm{q} / \mathrm{ha}$, which was $52.30 \%$ more than the control. The extension index and technology index were 34.34 and $19.44 \%$ respectively indicating high feasibility of its adoption among farmers. 
This variety has become popular in the area, because of its high yield and non-specificity to a particular season.

\section{Pea}

While evaluating the performance of the variety Arkel at farmers' field and comparing their performance with existing varieties. It was observed that variety Arkel performed very well in the farmers' field with technology index of $19.5 \%$, which resulted in better adoption and replacement of other varieties of pea in Bastar region.

Technology index of $19.5 \%$ was on lower side, indicting the high adoption of this variety by the farmer. This variety showed a $23.40 \%$ yield increase over local check.
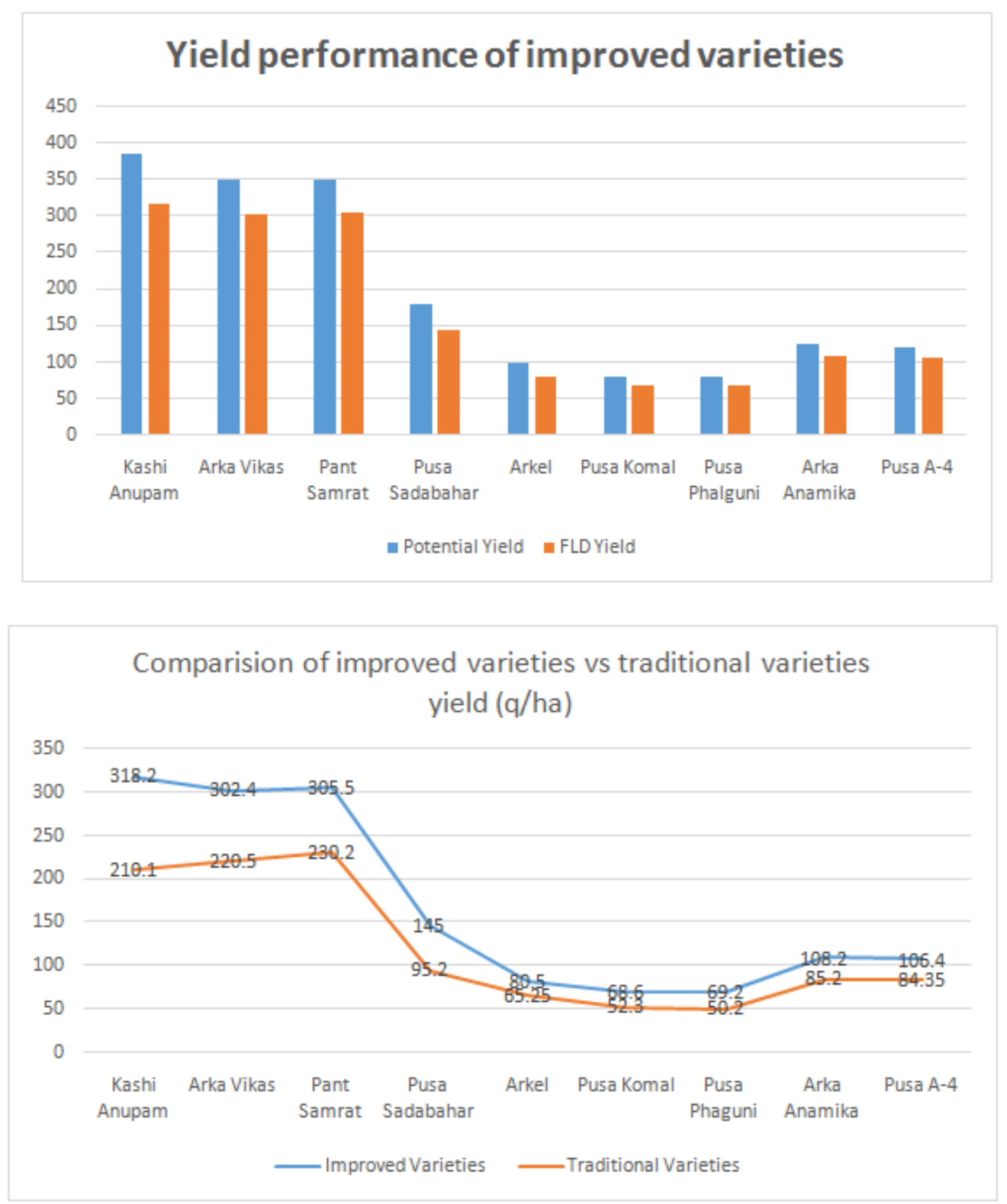


\section{Int.J.Curr.Microbiol.App.Sci (2017) 6(11): 1671-1677}

Table.1 Yield performance of demonstrated variety and existing cultivars

\begin{tabular}{|c|c|c|c|c|c|c|c|c|c|c|c|}
\hline \multirow[t]{2}{*}{ Crop/ Variety } & \multirow{2}{*}{$\begin{array}{c}\text { No. of } \\
\text { farmers }\end{array}$} & \multirow{2}{*}{$\begin{array}{c}\text { Demonstrated } \\
\text { Area }\end{array}$} & \multicolumn{3}{|c|}{ Yield (q/ha) } & \multirow{2}{*}{$\begin{array}{c}\text { Gap between } \\
\text { potential and } \\
\text { FLD Yield } \\
\text { (q/ha) }\end{array}$} & \multirow{2}{*}{$\begin{array}{c}\% \text { yield } \\
\text { increase } \\
\text { over } \\
\text { control }\end{array}$} & \multirow{2}{*}{$\begin{array}{l}\text { Technology } \\
\text { gap (q/ha) }\end{array}$} & \multirow{2}{*}{$\begin{array}{l}\text { Extension } \\
\text { gap (q/ha) }\end{array}$} & \multirow{2}{*}{$\begin{array}{l}\text { Technology } \\
\text { index }(\%)\end{array}$} & \multirow{2}{*}{$\begin{array}{l}\text { Extension } \\
\text { index }(\%)\end{array}$} \\
\hline & & & Potential & FLD & Control & & & & & & \\
\hline \multicolumn{12}{|l|}{ Tomato } \\
\hline Kashi Anupam & 17 & 0.8 & 385 & 318.20 & 210.10 & 66.8 & 51.45 & 66.8 & 108.10 & 17.35 & 33.97 (II) \\
\hline Arka Vikas & 13 & 0.8 & 350 & 302.40 & 220.50 & 47.6 & 37.10 & 47.6 & 81.90 & 13.60 & $27.08($ IV) \\
\hline \multicolumn{12}{|l|}{ Brinjal } \\
\hline Pant Samrat & 12 & 0.8 & 350 & 305.50 & 230.20 & 45 & 32.70 & 44.5 & 75.30 & 12.71 & $24.65(\mathbf{V})$ \\
\hline Pusa Sadabahar & 12 & 0.6 & 180 & 145.00 & 95.20 & 35 & 52.30 & 35.0 & 49.80 & 19.44 & 34.34 (I) \\
\hline \multicolumn{12}{|l|}{ Pea } \\
\hline Arkel & 16 & 1.5 & 100 & 80.50 & 65.25 & 19.5 & 23.40 & 19.5 & 15.25 & 19.50 & $18.94(\mathbf{I X})$ \\
\hline \multicolumn{12}{|l|}{ Cowpea } \\
\hline Pusa Komal & 11 & 1.5 & 80 & 68.60 & 52.30 & 11.4 & 31.20 & 11.4 & 16.30 & 14.25 & $23.76(\mathbf{V I})$ \\
\hline Pusa Phaguni & 14 & 1.5 & 80 & 69.20 & 50.20 & 10.8 & 37.80 & 10.8 & 19.00 & 13.50 & 27.45 (III) \\
\hline \multicolumn{12}{|l|}{ Okra } \\
\hline Arka Anamika & 13 & 1.5 & 125 & 108.20 & 85.20 & 16.8 & 27.00 & 16.8 & 23.00 & 13.44 & 21.25 (VII) \\
\hline
\end{tabular}




\section{Cowpea}

Two varieties of cowpea, Pusa Komal and Pusa Phalguni were demonstrated at farmers field and recorded an average yield of 68.60q/ha and 69.20q/ha, respectively. Pusa Phalguni was an out yielder and it has given $37.80 \%$ increase over local check. While in case of Pusa Komal percent increase over check was $31.20 \%$. Performance of both the variety was a par with technology gap of 11.4 and 10.8, respectively. Technology index in both the varieties observed were 14.25 and 13.50 respectively, showing better adoption and replacement of other varieties of cowpea.

\section{Okra}

Okra variety Arka Anamika and Pusa A-4 was also demonstrated at farmers' field an average yield of $108.20 \mathrm{q} / \mathrm{ha}$ and $106.40 \mathrm{q} / \mathrm{ha}$ was observed respectively. Percent increase over local check in both the variety was $27.0 \%$ and $26.10 \%$, respectively. Although the yield performance of both the varieties were at par, but the technology index of Pusa A-4 and Arka Anamika was (11.33\%) and (13.44\%) respectively on lower side, indicating high levels of adaptation of Pusa A-4 and Arka Anamikain the field, so these varieties are gaining popularity among the farmers.

Although, the field trial was laid down under the guidance of scientist at farmer's field, but a gap between potential yield and trial yield exist, which range from $10.8 \mathrm{q} / \mathrm{ha}$ in cowpea (Pusa Phalguni) to 66.8q/ha in tomato (Kashi Anupam). Such variation may be due to soil fertility and agro-climatic conditions. Hence, the local specific recommendations are necessary to bridge this gap. Extension index was also observed ranging from 18.94 in pea variety (Arkel) to $34.34 \%$ in chilli variety Pusa Sadabahar, it may be due to more traditional farming practices followed in this region. It can be reduced by giving more front line demonstration in the district and motivating farmers for adopting improved vegetable technology (Neeraj et al., 2008). Since the technology index of all the demonstrated varieties were in range of $11.33 \%$ to $19.5 \%$, which lies in the lower quarter, indicated the opportunities of high level of adoption.

Now, it is concluded that the existing extension gap can be bridge through participatory approach (Mukhopadhyay, 2002). The extension agencies can effectively communicate the improve technologies to farming community for better production. Similar findings have also been reported by kadian et al., (1997) in oilseeds. Singh et al., (2002) in pulses, Singh et al., (2002) and Gupta et al., (2004) in soya bean, and Rai et al., (2005) in solanaceous vegetables. The present study revealed that there is great scope of vegetable cultivation in the district and more extension services in community approach will certainly enhance the production and productivity along with improving the livelihood of the farmers.

\section{References}

Gupta B S, Kushwaha R S and Tiwari K P (2004). Effect of frontline demonstration on soybean yield in northern hills zone of Chhattisgarh. Indian Res, J. Ext. Edu. 4(182): 41-42.

Kadian K S, Sharma R and Sharma A K (1997). Evaluation of frontline demonstration trial in oilseed in kangra valley of himachal Pradesh. Annals 18(8): 43.

Mukhopadhyay S D (2002). Enhancing crop productivity through participatory approach. Indian J. Ext. Edu. XXX VII (182).

Pandey P K, Singh Neeraj and Pandey K K (2003), Annual report 2002-03 
submitted under NATP mission mode sub project on "variation and promotion of IPM technology in selected crops in different agro-ecological regions: IIVR, Varanasi.

Rai M, Singh N, Singh B and Singh M (2005), Performance of improved varieties of solanaceous vegetable crops at farmers field in eastern Uttar Pradesh. Veg. sci. 32(1): 69-72.

Singh A, Singh L and Prasad R (2002). Effect of frontline demonstrations on pulses yield during different seasons in Uttar Pradesh. Indian res. J. Ext. Edu. 2(2): 64-55.
Singh N, Choudhary B R, Rai A B, Rai A, Rai A K \& Rai M (2008), Evaluation of improved vegetable varieties through community approach in Kushinagar district of Uttar Pradesh. Veg. Sci: 35(2), 172-175.

Singh Neeraj \& Ram D (1999). Specific technology adopted and constraints faced by the farmers in hill. Indian J. Hill farming 122(182): 97-99.

Singh SP, Chitle S and Patel J R (2002). Effect of improved and farmers technique on the gain yield and economics of soybean. Bharatiya Krishi Anusandhan patrika (283): 160-163.

\section{How to cite this article:}

Ashwini Kumar Tiwari and Jugul Kishor Tiwari. 2017. Community Approach: A Novel Way to Assess the Performance of Improved Vegetable Varieties. Int.J.Curr.Microbiol.App.Sci. 6(11): 1671-1677. doi: https://doi.org/10.20546/ijcmas.2017.611.200 